2014

\title{
Revolution Imagined: Cause Advocacy, Consumer Rights, and the Evolving Role of NGOs in Thailand
}

Frank W. Munger

New York Law School, frank.munger@nyls.edu

Follow this and additional works at: https://digitalcommons.nyls.edu/fac_articles_chapters

Part of the Comparative and Foreign Law Commons, Consumer Protection Law Commons, Legal Profession Commons, and the Nonprofit Organizations Law Commons

\section{Recommended Citation}

Munger, Frank W., "Revolution Imagined: Cause Advocacy, Consumer Rights, and the Evolving Role of NGOs in Thailand" (2014). Articles \& Chapters. 1134.

https://digitalcommons.nyls.edu/fac_articles_chapters/1134 


\title{
Article
}

Frank Munger*

Revolution Imagined: Cause Advocacy, Consumer Rights, and the Evolving Role of NGOs in Thailand

\begin{abstract}
This article describes the founding and evolution of a "Thai-style" NGO dedicated to consumer protection. Through a description of the NGO and the career of its founder, the article brings to light features of the evolution of NGObased advocacy in Thailand from the student uprising in 1973 to the present. The legacy of the 1973 October Generation of activists continues to influence development of NGOs but new emphasis on rights has emerged since the era of constitutional reform in the 1990s. Many NGOs now make use of litigation to attempt to achieve social change, but litigation, like other long-standing methods of advocacy involving reliance on networks that penetrate government itself, reflect the particular opportunities and pathways for change opened by Thailand's politics.
\end{abstract}

Keywords: litigation, Thailand, consumer rights

DOI 10.1515/asjcl-2013-0054

\section{INTRODUCTION}

The student-led uprising on 14 October 1973, which toppled Thailand's military dictator, and a three-year period of vibrant democracy that followed have been long remembered by the so-called October Generation as a moment of shared expectation and a reminder of the moral value of constitutionalism and political liberalisation. The moment ended with a brutal crackdown on 6 October 1976 that slaughtered students, led to arrest and trial for many more, and forced hundreds of individuals to seek sanctuary with communist cadres on Thailand's borders. The restoration of the dictator to power has had lessons of its own for

*Corresponding author: Frank Munger, New York Law School, New York, NY, USA, E-mail: Frank.Munger@nyls.edu 
Thai social change advocates about the largely undiminished strength of the military, its allies, and the institutions they supported. Notwithstanding this "interruption" of the social revolution, the legacy of October 1973 nourishes the imaginations of later generations of activists for social change and political reform. ${ }^{1}$ Historians Chris Baker and Pasuk Phongpaichit observe that the October Generation students, after having felled a dictatorship and participated in a guerrilla war, "went on to have a profound effect on the following decades" during which they "spread the ideas of democracy, social justice, and Buddhist compassion more widely through society."2

Benedict Anderson's seminal essay on the October uprising has suggested that the uprising's importance lay not only in the ideals of participants but something more fundamental, namely successful non-elite participation in a political system historically dominated by elite insiders. ${ }^{3}$ Anderson concluded that the two events, uprising and crushing reprisal, are keys to understanding contemporary political struggle in which entrenched, traditional elites struggle to adapt to the emergence of new, potentially powerful social groups. Neither Thailand's institutional structure nor the distribution of power was fundamentally changed by the immediate effects of 1973. In the decades which have followed, efforts to extend the protection of rights and broaden political participation have encountered resistance from entrenched elite and military at every stage. ${ }^{4}$ Yet the landscape had changed. New resources and new opportunities for social and political activists were emerging. Potent and increasingly politically active popular groups challenged the monopoly previously exercised by Thailand's entrenched "bureaucratic polity" of the 1960s, comprised of military and business elites linked to powerful members of the bureaucracy. Notwithstanding the uprising's success, the dictatorship's return in 1976 revealed the fragility of the October Generation's power to lead, and the conditions under which they might succeed in the future were far from self-evident.

1 Haberkorn (2011) characterises poor farmers' post-1973 resistance to land seizures as evidence that a true revolution was underway, and she speculates about how this "interrupted" revolution might move forward. Tyrell Haberkorn, Revolution Interrupted (Madison, WI: Wisconsin University Press, 2011).

2 Chris Baker \& Pasuk Phongpaichit, A History of Thailand (Cambridge: Cambridge, 2005) at 198.

3 Benedict Anderson, "Withdrawal Symptom" in Benedict Anderson, ed., The Spectre of Comparisons: Nationalism, Southeast Asia and the World (London: Verso, 1998).

4 Duncan McCargo, "Introduction: Understanding Political Reform in Thailand" in D. McCargo, ed., Reforming Thai Politics (Copenhagen: Nordic Institute of Asian Studies, 2002).

5 Fred W. Riggs, Thailand: The Modemization of a Bureaucratic Polity (Honolulu: East-West Center, 1966). 
The uncertainty of their continuing role in Thai politics after 1976 invites closer examination of when and how its members, and those following in their footsteps, have attempted to make the ideals of 1973 active through efforts to bring about social change.

This article examines the evolution of post-1973 advocacy for social change in Thailand viewed through a case study of consumer rights. The advocate at the center of the study, Saree Aongsomwang, is a trained nurse who became manager of an NGO created to coordinate primary health care projects in 1989. By the mid-1990s she was leading consumer advocacy in a new direction by establishing the Foundation for Consumers ( $\mathrm{FFC}$ ) to promote consumer rights, and the Foundation's pioneering use of litigation is now at the forefront of a new phase in social change advocacy in Thailand. This case study examines the network of non-governmental organisations (NGOs) on which Saree has built her career. The Thai NGO movement, and the individuals who created and maintain them, form a network of organisations and relationships that extend to a larger community of potential allies and, at times, into government offices. As I explain in subsequent parts of this article, this resilient and adaptive network has evolved over several interconnected generations, both backwards in time to the October Generation and earlier social cause advocates, and forward to Saree's generation and younger advocates. Notwithstanding her evolution as a modern advocate for consumer rights, Saree's perception of her role and many of her strategies for advocacy have their roots in movement-oriented NGO culture of the 1970s, and especially the strong connection she makes between empowerment, a goal at the core of 1973 political ideology, and the rights of individual consumers.

Theories of social movements and social advocacy have long emphasised the importance of context and the conditions that influence a movement's cause and facilitate or impede the development of capacity and its leaders' choice of strategies. ${ }^{6}$ Similarly, Saree Aongsomwang's career and the development of a network of NGOs supporting social causes reflects the evolving context for

\footnotetext{
6 Douglas McAdam et al., "Introduction: Opportunities, Mobilizing Structures, and Framing Processes - Toward a Synthetic, Comparative Perspective on Social Movements" in Douglas McAdam et al., eds., Comparative Perspectives on Social Movements: Political Opportunities, Mobilizing Structures, and Cultural Framings (Cambridge: Cambridge University Press, 1996). Scholars Austin Sarat and Stuart Scheingold (2003), writing about "cause lawyers," emphasise the importance of institutions that influence lawyers' social change advocacy, especially the political and administrative constraints and openings created by the State. Austin Sarat \& Stuart Scheingold, "What Cause Lawyers Do For, and To, Social Movements: An Introduction" in Austin Sarat \& Stuart Scheingold, eds., Cause Lawyers and Social Movements (Stanford, CA: Stanford Cambridge University Press, 2003). See also Frank W. Munger, et al., "Mobilizing Law for Justice in Asia” (2014) 31 Wisc. Int'l. L.J. forthcoming.
} 
advocacy in Thailand, including the continuing presence of a powerful Thai administrative bureaucracy, sharp changes in political climate and institutional development, and the opportunities and openings created through connections to international sponsors and other resources. I pay close attention to the continuing influence of three important resources derived from the 1973 uprising: (1) the means by which leaders have sought legitimacy for their causes, (2) networks in which activists have been embedded, and (3) the role of rights. The 1973 uprising played a role in creating each of these resources for advocates for social change, but their utilisation and influence on advocacy has been shaped by adaptation to Thailand's evolving politics and institutions. While it has been suggested that Thai NGOs that cooperate with government have become depoliticised, I argue in this article that Thai-style NGOs carry forward the legacy of 1973 by a route that is different from community-based social movements which have attracted more attention from scholars. ${ }^{7}$

This case study is based in part on detailed interviews conducted over the past 7 years with over two hundred legal practitioners and NGO-based cause advocates as well as with Thai scholars, government officials, judges, and ministry officials with knowledge of the history or context of cause advocacy in Thailand. ${ }^{8}$ For a particular social cause, individuals were selected through a wide range of contacts in Thailand, newspapers, and secondary literature. These initial contacts led to a much larger pool of potential interviewees that includes many of Thailand's most prominent advocates as well as others who are less wellknown and younger individuals. Other sources such as government documents in Thai, NGO records, Thai newspapers, selected Parliamentary documents, and websites, both in Thai and in English have also been consulted but much of the history of social cause advocacy and the evolution of Thailand's NGO movement remains poorly documented, and oral history remains my principal source.

\section{The making of an October Generation}

The October Generation is a product of the expansion of Thai universities in the 1960s. Partly because American advisors demanded educational development

\footnotetext{
7 Amara Pongsapich, "Thai Political Space for Advocacy" in Joel Paredes et al., eds., Breaking Through: Political space for Advocacy in Southeast Asia (Quezon City, Philippines: Southeast Asian Committee for Advocacy, 2007) at 226.

8 Interviews were conducted in Thai by a native speaker, transcribed in Thai and thereafter translated into English. For background, see Frank W. Munger, "Globalization, Investing in Law, and the Careers of Lawyers for Social Causes - Taking on Rights in Thailand” (2008-9) 53/4 N.Y.L. Sch. L. Rev. 745.
} 
but also because Thai families seeking upward mobility in an expanding economy wanted to educate their children, the Thai government expanded the educational system at the high school and university levels in the 1960s and 1970s. Thammasat University, located in Bangkok, became the center of student radicalism. Programs sent undergraduates to the countryside to study Thailand's social conditions, to talk with villagers, and to help where they could. ${ }^{9}$ Before 1973, visits to the countryside revealed to many students widespread deep poverty and the inadequacy, oppressiveness and corruption of the Thai government. The Thai NGO movement began during the student visits to the countryside before 1973. The first NGOs were created to undertake projects to assist long-neglected communities in both the rural countryside and the urban slums. After 1973, the number of NGOs and the level of student involvement escalated, including projects to support labor actions by workers, resistance by farmers to land seizures, and other powerful social movements.

Consumer protection, in the sense understood by citizens in Western societies - product pricing and manufacturers' liability - may seem marginal to the deeper political issues that troubled the students and their allies. Yet the underlying economic anxieties of many of those who joined the students were, in part, evidence of a growing awareness of the power of market forces beyond the control of the local and intimate collectivities of a traditional society. Underlying ideas such as empowerment, participation, and accountability one can see concern about poverty and the unequal distribution of the benefits of Thailand's emerging market society. Rural medical practitioners were among the first to take up advocacy for broad changes in the policies affecting the health and wellbeing of the poorest and most underdeveloped regions. ${ }^{10}$ Influenced by their own experiences as rural practitioners, they readily connected with students eager to learn about their own society. Beyond the vision of the protesters and most Thai, an international movement was already transforming the discourse of "underdevelopment" assistance that had legitimated the U.S. role in Thailand in the $1960 \mathrm{~s}$ into a discourse of Primary Health Care and, closely intertwined, a growing international movement on behalf of poor consumers. The experiences of rural doctors and the new international discourse of development through primary

9 Puey Ungphakorn, A Siamese for All Seasons: Collected Articles by and About Puey Ungphakom, 5th ed. (Bangkok: Komol Keemtong Foundation, 2000).

10 According to Bamber, many of the doctors had treated enough people who had been shot, beaten or tortured by the police and military to be well acquainted with the injustices perpetrated under military rule. Scott Bamber, "The Thai Medical Profession and Political Activism" in Kevin Hewison, ed., Political Change in Thailand: democracy and participation (London: Routledge, 1997). 
health care and consumer protection, in different ways and by different pathways, shaped the development of consumer advocacy.

Medicine has long been Thailand's most prestigious profession, and at midtwentieth century, the only graduate degree offered by any Thai university providing a means to a secure social and financial future and opportunities abroad. ${ }^{11}$ Yet medical students were among the leaders of the protests. ${ }^{12}$ Medical students chose to visit the countryside in increasing numbers, accompanied by doctors with intimate knowledge of the inadequacies of government administration of medical services. Dr. Prawet Wasi wrote that before 1973 almost the entire graduating class of Chiangmai medical school went to practice in the U.S., ${ }^{13}$ but the events of 1973 inspired many young doctors to practice in rural areas. Students organised projects to provide better health care for slums and villages and became advocates both for health care reform and greater justice for rural Thai.

Medical students of the October Generation were well-received by rural practitioners who were already well-acquainted with poor health care and other problems of rural Thai communities. ${ }^{14}$ Doctors embedded in rural practice were in a good position to create connections between communities, to communicate ideas about improving health care, and to become the voice of community concerns. It is hardly surprising that many of them worked with newly formed NGOs broadly promoting community development or formed NGOs of their own. ${ }^{15}$

11 Philip Donaldson, "Foreign Intervention in Medical Education: A Case Study of the Rockefeller Foundation's Involvement in a Thai Medical School” in Victor. Navarro, ed., Imperialism, Health, and Medicine (Farmingdale, NY: Baywood Publishing Co, 1974).

12 Bamber, supra note 10.

13 Prawet Wasi, บนเส้นทางชีวิตขบวนการแพทย์ชนบทในประเทศไทย. [On the Path of the Rural Doctor Movement in Thailand] (Bangkok: Folk Doctor Publications, 2000); Suwit Wibulpolprasert, จากสหพันธ์แพทย์ชนบท ถึง ชมรมแพทย์ชนบท และมูลนิธิแพทย์ชนบท [From the Rural Doctor's Federation to the Rural Doctor's Club and Rural Doctor's Foundation] (2003). Found at <http://www.moph.go.th/ngo/rdf2.htm> (last visited 9 May 2013).

14 From 1949, Dr. Sem Pringpuangkeo, long identified with health care reform in Thailand, lobbied for development of rural health facilities. As part of its public health expansion program in the 1960s, the Thai government embarked on construction of a hospital in every administrative district. The expansion, in turn, greatly increased the number of doctors assigned to rural areas and the potential base for a rural doctor's movement. In 1968, rural doctors persuaded the Thai government to establish a Medical Council to take up issues of medical advancement. In 1969, the same group of practitioners succeeded in winning government support for a conference on the ethical responsibility of doctors to promote development. Suwit Wibulpolprasert, 25 ปี ขบวนการแพทย์ชนบทกับแผ่นดินไทย [Twenty-Five Years of the Rural Doctor's Movement] (Bangkok: World Health Organization, 2003).

15 As Bamber points out, the government doctors were rotated between posts, maintaining connections to the university and to other professionals. Supra note 10. Bamber also suggests that a decade or two later doctors were among the first users of mobile phone technology, making them valuable allies in collective action. 
After 1973, doctors founded a number of important NGOs to address primary health care needs, and the influence of some of them has survived well beyond the crackdown in 1976 as members of Saree Aongsomwang's influential network. ${ }^{16}$ The Drug Study Group, founded in 1975, addressed widespread improper use of pharmaceuticals, re-emerging after the crack-down and amnesty in 1980. The Population and Community Development Association established in 1974 combined family planning and primary health care, one of the first with a broad community development mission. At about the same time, a number of experienced rural doctors who shared similar views about the need for development of rural health care delivery and welfare formed the Rural Doctors Federation (RDF) to "support public health policies that truly benefit the majority of the citizens of the country." 17 Shortly after establishing the RDF, the Federation applied to the Ministry of Public Health for funding for a study visit to China, a leader in rural medical delivery.

The October 1976 crackdown ended the activities of the RDF and most of the fledgling NGOs were suppressed and their staff members disbanded, arrested or forced to flee. Many of the doctors were labeled communists for their activities and fled to the jungle or hid. Even older and respected members of the profession, such as Dr. Prawet Wasi, came under suspicion. ${ }^{18}$ But the restoration of the dictatorship was not the end of their influence. Activists forced to flee under threat of arrest in 1976 were granted amnesty in $1980^{19}$ and again permitted to play a role in Thai society. Enterprising members of the October Generation founded new NGOs and supported new social movements. The activities they had undertaken as students, and the networks which they created, helped build a closely networked NGO community after 1980, unified in its support for popular welfare and political liberalisation. ${ }^{20}$

16 Among the better known activists, Dr. Prawet Wasi founded the Folk Doctor Association in 1976 to train Monks in basic medicine. Wasi was a prominent senior practitioner whose status aided the cause of rural doctors and later the movement for liberal constitutional reform. Bamber, supra note 10.

17 Wibulpolprasert, supra note 14 at 3.

18 Bamber, supra note 10.

19 Prime Ministerial Order 66/2523 (1980).

20 Ernst W. Gohlert, Power and Culture: The Struggle Against Poverty in Thailand (Chonburi, Thailand: White Lotus Press, 1991). 


\section{Liberal ELITES AND INTERNATIONAL MOVEMENTS - A SECOND PATH OF REFORM}

Saree's career as an activist has been influenced both by the ideal of empowerment and the establishment of NGOs, both of which are legacies of the era of the uprising, but also by a second path of reforms linked to the uprising through the intervention of elites and individuals who might be called "cause bureaucrats." Although the restored dictatorship ended the brief democratic experiment and disbanded most NGOs, important policy changes were adopted by the authoritarian government that provided additional momentum for consumer advocacy.

Restoration of the dictator returned the military to power in a ruling coalition of elites. A governing network of military leaders, bureaucrats, and the royal family excluded other groups from meaningful political participation creating a "bureaucratic polity," a term capturing the closure of Sarit's government to political interests outside the alliances linked to the bureaucratic state. ${ }^{21}$ High ranking ministers in government departments were influential in this coalition and relatively unresponsive to bottom up pressure from those they serviced or regulated. Historically competitive relationships among ministries, their relative insularity and patron-client internal hierarchy have had long-lasting effects, even as administrators have become more professionally competent. ${ }^{22}$ Lacking oversight by administrative courts and insulated from bottom up political pressure, the powerful position of Thai bureaucracies has considerably narrowed the space for advocates to influence bureaucrats.

The ruling network has not been without its own dynamics and upheavals, and it has evolved to incorporate groups of new contenders for power as they emerged. ${ }^{23}$ An important implication of Anderson's analysis of the uprising of 1973 is that the polity was in the process of expanding. Liberal elites shared the humanitarian goals of the rural doctors and October Generation students, and some were themselves October Generation members who later entered

21 Thak Chaloemtiarana, Thailand: The Politics of Despotic Paternalism (Ithaca, NY: Cornell 2007).

22 Although administration has become more professional over time, especially at the national level, many of these qualities persist to the present time. Herbert J. Rubin, "Rules, Regulation and the Rural Thai Bureaucracy" (1980) 11 Journal of Southeast Asian Studies 50; Robert Muscat, Thailand and the United States: Development, Security and Foreign Aid (New York: Columbia University Press, 1994); James Ockey, "State, Bureaucracy, and Polity in Modern Thai Politics" (2004) 34 Journal of Contemporary Asia 143.

23 As Anderson predicted when his essay was first published in the 1970s, in the latter part of the twentieth century, governments in Thailand have increasingly needed popular and business community legitimacy, and the military's role has been increasingly challenged and reduced. 
government service as advisors to politicians, officials in ministries or even members of Parliament. ${ }^{24}$

The restored military dictator's heavy handed reprisals and slow return to economic development quickly became a liability, and a series of military coups brought a more moderate dictator to power, General Kriangsak Chomanand. ${ }^{25}$ Kriangsak was expected not only to stabilise domestic politics but also to respond to a growing international human rights movement and, more specifically, to critics in the U.S. Congress who questioned Thailand's human rights record. On the domestic front, Kriangsak's government countered rural discontent by establishing many rural development projects. ${ }^{26}$ On the international front, the Kriangsak government responded favourably to international projects of humanitarian reform, including the international movement for primary health care and the closely related movement for protection for poor consumers. The government's receptivity to these international initiatives may show its sensitivity to accusations of human rights violations but more clearly reflects the influence of liberal elites in position to collaborate with cause bureaucrats.

Core members of the RDF, spared the excesses employed against less elite groups, reorganised themselves in 1977 as the repression eased, naming themselves the Rural Doctors Club (RDC). Although the Club was established with the support of a number of older, elite members of the profession, it was viewed initially with suspicion by the military government. ${ }^{27}$ The revival of the rural doctor's movement with the formation of the RDC in 1977 bore immediate fruit in grants for rural medical care from European and Japanese funders. In September 1977, the Ministry of Public Health and WHO jointly sponsored Thailand's first National Conference on Primary Health Care in Chiang Mai (notably, not in Bangkok), and in 1979, the government declared development of primary health care the national policy for public health. ${ }^{28}$

A closely related international movement led by the International Organization of Consumers Unions [IOCU] pressured developing countries to provide greater protection of poor consumers. The IOCU's Penang, Malaysia

24 Wibulpolprasert, supra note 15; Duncan McCargo, "Network Monarchy and legitimacy crises in Thailand" (2005) 18 The Pacific Review 499.

25 Baker \& Phongpaichit, supra note 2.

26 Andrew Walker, Thailand's Political Peasants: Power in the Modern Rural Economy (Madison, WI: The University of Wisconsin Press, 2012).

27 Wasi himself was the founder of the "folk doctor" movement but also an elite advocate for liberalisation. But because the social background of many of the leaders of the Club (and indeed many successful members of the profession) is Sino-Thai, the association was viewed by the MOPH at first as a kind of "Chinese Gangster association." Wibulpolprasert, supra note 14 at 5. 28 Wibulpolprasert, supra note 14. 
office founded global networks focused on family nutrition, safe breast-feeding, and misuse of prescription drugs, all issues of great concern to advocates for health care for the poor. ${ }^{29}$ The National Women's Council of Thailand, organised by Queen Sirikit in 1956 to promote the welfare of the poor and needy ${ }^{30}$ met with a representative from the IOCU in $1969 .^{31}$ The NWCT created a consumer protection committee, which within a few years, proposed adoption of a consumer protection law. The NWCT joined with another elite organisation, the Consumer Protection Association of Thailand, founded in 1971 by two doctors, one of whom was the Permanent Secretary of the Ministry of Public Health, and the other an important member of the rural doctors' movement, ${ }^{32}$ to put its proposal before General Kriangsak's administration in $1978 .{ }^{33}$ The CPA's formal mission statement reflected the IOCU's own charter emphasis on consumer rights and product testing, but the Thai organisation, like similar organisations in Malaysia and elsewhere in Asia, was primarily concerned about the nutrition and sanitation of poor families.

Prior to the adoption of the Consumer Protection Act of 1979, Thailand had many laws on the books to protect consumers from misrepresentations in sales, false labeling of goods, unsafe products, and unfair pricing of goods. ${ }^{34}$ A study of Thai consumers undertaken in the late 1970s emphasised the limitations of these laws, which were seldom utilised by consumers and even more rarely enforced. ${ }^{35}$ Consumers lacked knowledge of their rights, ${ }^{36}$ and even if they felt

29 Stephen Brobeck, ed., Encyclopedia of the Consumer Movement (Santa Barbara, CA: ABCCLIO, Inc., 1997).

30 Philip Doneys, "Political Reform thorough the Public Sphere: Women's Groups and the Fabric of Governance" in Duncan McCargo, ed., Reforming Thai Politics (Copenhagen: Nordic Institute of Asian Studies, 2002).

31 Wilaikul Rattinai, เภสัชกรดีเด่นสาขาเภสัชวิทยาการปี 2524 ผู้บุกเบิกงานคุ้มครองผู้บริโภค [The Development of the Consumer Promotion Project by the National Women's Council] in The Consumer Handbook (Bangkok: National Women's Council \& Consumer Protection Association, 1999).

32 See <http://www.comsumerprotection.or.th/index.php?mo=10\&art=579212> (last visited 6 August 2013).

33 Rattinai, supra note 31.

34 For example, the Food Quality Control Act of 1974 regulated quality and sales practices for many staples sold for household consumption. Research undertaken in Malaysia by the Regional Office of the IOCU suggests that mislabeling ingredients and quality control were massive problems throughout Asia. See Hans B. Thorelli \& Gerald D. Sentell, Consumer Emancipation and Economic Development: The Case of Thailand (London: JAI Press, 1982).

$35 \mathrm{Ibid}$. Thorelli and Sentell attribute lack of enforcement to bureaucratic inefficiency and corruption but more fundamentally to the lack of initiative on the part of consumers themselves. $36 \mathrm{Ibid}$. More than $50 \%$ believed that if they purchased a defective product they had no right to complain. Tables X.6, X.7 \& X.8. 
that they had been treated wrongly they were unlikely to take action. ${ }^{37}$ The researchers concluded that Thai consumers had low expectations, and whatever expectations they had were probably exceeded because Thailand's increasing prosperity gave them access to many new products which they wanted to buy. ${ }^{38}$

The Consumer Protection Act of 1979 formally recognised broad government responsibility for the quality of food, services, and medicines and responsibility to address complaints brought by the public. Yet, the Act, like many organic laws drafted by Thai ministries, gave broad discretion to bureaucrats to say when and under what rules the bureaucracy would act. The law created a right to complain but no rights to take action against sellers or service providers. A Consumer Protection Board created by the Act retained discretion to take action against business owners. ${ }^{39}$ High-ranking government officers and heads of ministries made up a majority of the Board, ensuring that little action would be taken to disturb relationships within the ruling elite. Through a number of expert subcommittees, the Board had authority to decide which goods and services would be regulated and to specify the quality of products and services. An Office of the Consumer Protection Board (OCPB) was given authority to conduct research and to promote consumer education, among other responsibilities. ${ }^{40}$ According to Thai consumer advocates, administration of these responsibilities was slow to develop and inadequate. In the view of grassroots activists, the efforts of the OCBP and the OCPB still left consumers poorly informed about their rights and widespread consumer problems inadequately addressed. ${ }^{41}$

37 Ibid. Table X.10.

38 Ibid. Other data gathered for the study suggested that consumers were conflict averse, reporting reluctance to confront a seller or manufacturer. A recent study found culture an important contributor to avoidance of personal injury litigation. David M. Engel \& Jaruwan S. Engel, Tort, Custom, and Karma: Globalization and Legal Consciousness in Thailand (Stanford, CA: Stanford University Press, 2010).

39 Consumer Protection Act of 1979, s. 10.

40 Consumer Protection Act of 1979, s. 20.

41 Like a great deal of Thai social welfare legislation on the books, administration of the Act lagged according to Taewee Photipala, Professor of Pharmacy at Sukhothai Thammathirat University, Director of Public Relations of the OCPB 1979-1983, Chair of the National Women's Council Consumer Protection Committee 1997-2000. Interviewed 10 July 2013 and 25 December 2013 (conducted by Peerawich Thoviriyavej and Vorapitchaya Rabiablok). Thai consumers may have underutilised the OCPB in part because they seldom sought remedies for consumer issues. Further, the OCPB perceives its primary role as setting standards for industry rather than protecting individual consumers. Complaints brought to the OCPB often result in compromises which are perceived to favour business. Ibid. 
The Act's most innovative provision promised much more by authorising approved consumer advocacy associations to "institute civil and criminal proceedings or bring any legal proceedings for the protection of the consumers," including suits for recovery of damages. ${ }^{42}$ This provision had far-reaching implications for the future. NGOs emerged from the shadows to pursue their work on primary health care and protection of consumers in the wake of the government's endorsement, although the new Consumer Protection Board delayed creating regulations authorising NGO litigation on behalf of consumers for several decades. ${ }^{43}$

Notwithstanding the government's delay in authorising NGOs to litigate on behalf of consumers, NGOs could have assisted consumers with their own litigation without additional authorisation, but individuals with consumer issues rarely considered pursing litigation, and, indeed, rarely pursued consumer issues at all. ${ }^{44}$ Although rights may have been understood as claims for justice, as the advocate Saree Aongsomwang discovered, they were not perceived as practical instruments for the protection of health, safety and well-being until much later. ${ }^{45}$ In the 1990s, rights and the importance of litigation acquired new meaning for advocates and perhaps a wider segment of the public during the push for constitutional reform. After constitutional reform in 1997, the Consumer Protection Act's long dormant provisions for litigation acquired new importance after adoption of the People's Constitution in 1997.

The Consumer Protection Act helped bring NGOs back into the picture of government administration. It is hardly surprising that the NGOs active prior to 1976 re-emerged as the leading advocates for primary health care following passage of the Act, leading the way toward a broader concern for consumers. The NGOs included the Consumer Protection Association, the Rural Doctors' Club, and soon, a new coalition of pre-existing primary health care NGOs called the Coordinating Committee of Primary Health Care NGOs (CCPN). How this

42 Consumer Protection Act of 1979, ss. 40 \& 41. Subsequent amendments, including the Consumer Protection Act of 1998 and the Consumer Protection Act of 2013, did not change the relevant parts of these sections.

43 Consumer Protection Act of 1979, s. 41 required ministerial regulations governing registration to litigate. PM Chavalit issued the first set of regulations on 9 September 1997, amid a rising tide of NGO power and a movement for constitutional reform. Ministerial Regulations 8 and 9 Pursuant to the Consumer Protection Act of 1979 (1997).

44 Interview with Professor Thaewee Photipala, supra note 42. This characterisation of consumer behaviour when the Consumer Protection Act was enacted may require some modification at present. Although Professor Photipala believes that some consumers are more willing to pursue remedies, Thai are still extremely reluctant to use the court system.

45 Saree Aongsomwang, Director, Foundation for Consumers. Interviewed 11 July 2011. 
occurred requires a closer look at the NGO movement itself and the careers of activists leading it.

\section{AN ADVOCATE'S JOURNEY tO CONSUMER EMPOWERMENT}

Saree Aongsomwang is a member of a third generation, an activist whose career began more than a decade after 1973. She has been influenced indirectly by the experiences of the October Generation and older advocates through friendships and mentoring and by working for organisations created by them. Their influence has taken root in own work as an advocate for social change under very different circumstances. ${ }^{46}$

Saree is from a family which owned a successful rubber plantation in Rayong, and she graduated from Chulalongkorn University nursing school in 1981. She recalls that her mother's fairness toward Burmese workers made a great impression on her, and her own strong sense of fairness was reinforced by student visits to the countryside. She remembers the small daily injustice she shared with many other ordinary Thai people of being forced to pay an illegal premium to a bus conductor on trips to and from Bangkok, an example of the many failures by the government to regulate and reform enterprises under its supervision. ${ }^{47}$ After graduation, Saree had to "work off" her tuition subsidy in a government hospital, but then changed direction, earning a Master's Degree in 1989 in social development at Thammasat University. She found work as manager of a "Thai-style" NGO, the Coordinating Committee for Primary Health Care NGOs (CCPN).

CCPN was organised in 1983 by Dr. Songuan Nittyaramphong, a leading member of the Rural Doctor's Club (RDC), to coordinate the work of 19 NGOs. ${ }^{48}$ CCPN was a "Thai-style" NGO, ${ }^{49}$ Thai-style NGOs have played a distinctive dual

46 Unless otherwise indicated, details which follow are based on my interview with Saree Aongsomwang, 11 July 2011.

47 Many bus operators are concessionaires operating under the oversight of a government ministry.

48 Dr. Nittayarompong shortly afterward became president of the Rural Doctor's Club. In the late 1990s, he proposed Thailand's current "Thirty baht" medical coverage which was adopted under Prime Minister Thaksin Shinawatra. Wibulpolprasert, supra note 15.

49 Chair of Chulalongkorn University's Department of Social Development, Amara Pongsapitch, has distinguished these organisations from a later generation of rights-based (rather than needs-based) civil society organisations in Thailand. Pongsapitch, supra note 5. Saree's advocacy has evolved to become rights-based but her Foundation for Consumers retains many of the characteristics of a Thai-style NGO. 
role in cause advocacy through close collaboration with government on one hand and willingness to use this relationship as leverage to oppose the decisions of government officials or to advocate for changes in policy on the other. Government ministries tolerated them because of their expertise, administrative capacity, and legitimacy with foreign donors. CCPN, like many other Thai-style NGOs, had connections with cause sympathetic bureaucrats and had been founded and staffed by activists who embraced the legacy of 1973 and a broad commitment to "empowerment" consistent with their origins.

For example, the 19 NGOs which became members of CCPN encompassed a range of issues which extended well-beyond traditional medical issues, including nutrition and other non-medical problems of the poor. Some had existed since the 1973-1976 era, for example, the Drug Study Group and the Rural Pharmacists Association. Others were of more recent origin, including the reconstituted Rural Doctors Club and the Voluntary Groups Supporting Consumer Protection, an association of small organisations representing a wide range of issues, including corruption in bus fare pricing and the nutritional value of breast milk substitutes. ${ }^{50}$ The origins of these NGOs insured that they shared the idealism of 1973, but more specifically that they were among the NGOs best positioned to become involved in Ministry of Health efforts to carry out the government's formal commitment to improving primary health care. CCPN was intended to give its members greater voice in dealings with government ministries, the media, and the public.

When Saree became manager, CCPN and RDC were collaborating to terminate the Thai Food and Drug Administration registration of numerous pharmaceutical drugs being used improperly, either beyond their expirations dates or utilised for purposes not intended by their manufacturer. ${ }^{51}$ This project and others were funded under a 3-year grant from Bread for the World, a German philanthropy focusing on poverty in developing countries. Saree prided herself

50 Andrew Turton suggested that the problems of widespread misuse of drugs was widespread and symptomatic of growing consumption and unregulated markets when CCPN was organised. He concludes, "It is noteworthy that many of the efforts of poor farmers to set up their own association, in conditions where political organization is most difficult, take the form of medical self-help projects... In this they are often helped by some of the alternative developmental organizations, recently formed consumer groups, and some concerned sectors of Thailand's highly advanced by unequally distributed medical system." Andrew Turton, "Limits of Ideological Domination and the Formation of Social Consciousness" in Andrew Turton \& Shigeharu Tanabe, eds., History and Peasant Consciousness in South East Asia (Osaka: National Museum of Ethnology, 1984) at 41.

51 In addition to my own interviews, other sources refer to this campaign. Wibulpolprasert, supra note 14 . 
on public relations campaigns, holding press conferences at memorable historic sites or employing other devices to add drama. For the drug campaign, she organised a provincial caravan to collect improperly used drugs, which were dumped with great fanfare at the front door of the Thai Food and Drug Administration in Bangkok. The campaign angered officials of the Ministry of Public Health who had a close relationship with big pharmaceutical companies, but CCPN had the support of the Minister of Public Health. Notwithstanding Saree's creativity, the CCPN prescription drug campaign failed to discourage continued widespread improper use of prescription drugs.

Because removing drugs from the market one at a time had failed, Saree began to rethink the NGO's strategy for social reform. She concluded that empowerment required a new direction, namely empowering people directly with information and the means to act on their own behalf. She proposed that CCPN undertake a 3-year pilot project to experiment with new approaches. Saree says that at that time no one in the movement thought much about the role of the consumer or the importance of consumer rights. She embraced the term consumer by making individuals the focus of change and consumer rights the key to consumer claims and remedies. ${ }^{52}$ Her proposed project was different from the work most characteristic of Thai-style NGOs, whose goal was reforming the bureaucratic state. Not limited to augmenting the government's weak enforcement efforts, her project was intended to inform the public of its rights and to encourage individual action by disseminating information, promoting public discussion, and community mobilisation to support individual complaints and other remedies. ${ }^{53}$ Saree's project could also be viewed as attempting nothing less than to change an historic relationship between Thai citizens and their government by asserting their individual rights.

CCPN's governing committee at first refused to support Saree's project, insisting that her proper role was coordinator, carrying out the member NGOs' priorities, not project developer. She thinks they changed their mind when they realised that she might leave to organise a rival NGO, and eventually they approved a pilot project that began in 1992. Even after winning the governing committee's approval, Saree's attempts to solicit support from member NGOs were rebuffed because they claimed they lacked the resources. The inflexibility of the NGOs and the governing committee of CCPN drove Saree to create a new

52 Shortly after Bread for World discontinued its funding for CCPN, Saree reported, because the NGO was now helping “rich people," reflecting, perhaps, Thailand's rising levels of income, but also the shift in the focus of Saree's advocacy.

53 Interview by ThaiNGO.org [in Thai] 20 November 2008 found at <http://www.thaingo.org/ story/info_009.htm> (last visited 29 December 2013). 
organisation, not to rival CCPN, but to finance and direct her new ideas. Supported by the Rural Doctors' Club, the Foundation for Consumers was registered in 1996. Consumer protection's time had arrived in Thailand.

\section{The Foundation for Consumers}

Saree's 1992 pilot project had three parts - a complaint center, a periodical, and a forum for exchange of information and ideas-capacity building for a consumer movement. ${ }^{54}$ The complaint center was up and running by 1994, and soon included outreach through a radio program and a column in a major newspaper. By then, she had also established a successful periodical, Smart Buy, to inform the public about products, consumer issues, and the remedies available to them. The third element of her project, a public forum that supported networking and other forms of capacity building, required more resources and more time. After the establishment of the Foundation for Consumers in 1996, she was able to launch a weekly television program to encourage public discussion, and with better funding she began to build self-sustaining consumer support networks at the provincial level.

Saree believed that promoting knowledge of consumer rights would encourage individuals to take action against a government agency or a private entrepreneur. The Consumer Protection Act of 1979 had established an Office of the Consumer Protection Board to receive and act on complaints. The OCPBs complaint process had two weaknesses, it was underutilised and the Board retained discretion about whether to pursue a complaint. ${ }^{55}$ Saree believed that members of the public lacked information about the process and would be better off if they had the capacity to pursue complaints without OCPB oversight. To address

\footnotetext{
54 Although Saree says that she did not model the Foundation on similar organisations outside Thailand, an active consumer protection center existed in Penang, Malaysia, and Saree was in contact with at least two of its networks, the breast feeding and pesticide networks. The Consumers Association of Panang was founded in 1970 and quickly became a leader in advocacy for poor consumers. See Brobeck, supra note 30 at 177 . See also <http://www. consumer.org.my/index.php/homepage/about-us/69-vision-a-mission> (last visited 4 April 2014).

55 Although the OCPB's activity seems irrelevant to Saree's current conception of her mission, the OCPB seems to have become more active over time. In recent years has undertaken significant consumer protection initiatives and receives between 500 and 1,000 complaints each month. Issues topping the list of complaints (e.g., membership at a fitness center) are distinctively urban and middle class. OCPB current monthly statistics are available at $\langle\mathrm{http}: / /$ www.ocpb.go.th/ewt_news.php?nid=384> (last visited 31 December 2013).
} 
the first, she lobbied the Thai FDA to provide self-addressed postcards returnable to the FDA which could be distributed through her publication Smart Buy. Although the FDA staff strongly opposed the request, the director of the FDA at the time was a member of the Rural Doctors Club and gave them a substantial sum for capacity building among consumers. The FDA eventually responded to the outpouring of popular interest through an outreach of its own by establishing a bounty system that rewarded consumers who reported problems by giving them part of any penalty or fine imposed on a business.

To give consumer's greater control of their complaints and the outcome, Saree's pilot project included development of a new complaint center to help individuals pursue complaints on their own. From its inception in 1994, the complaint center has been a resource for aggrieved consumers motivated to take action. ${ }^{56}$ Complaint center staff and volunteers helped individuals resolve their complaints by providing information, offering mediation support, and when litigation became a practical possibility at a later point, maintaining a pool of volunteer attorneys to advise and represent consumers.

To reach a broad audience, Saree has attempted to expand consumer awareness and action in regions further from Bangkok. Government funding for NGOs was available from the early 1990s under Prime Ministers Anand and Chuan, which Saree used as seed money to encourage creation of provincial networks for consumer protection. Government funding continues to provide important funding for consumer awareness campaigns. ${ }^{57} \mathrm{~A}$ weekly T.V. program featuring discussion of consumer issues helped to extend networks for consumer action into most provinces. In 2001, Saree hosted a conference attended by ten provincial consumer protection networks. Since that time, she says that consumer protection associations have been organised in almost all provinces. She has utilised this nationwide network to mount campaigns for national referenda, authorised by Thailand's 1997 Constitution, to enact no-fault medical care legislation, modeled on New Zealand's innovative system, and to enact an organic law establishing an independent consumer protection agency. ${ }^{58}$

56 Complaints received by the Foundation's Complaint Center number far fewer than those reported by the OCPB. While the OCPB provides no information about following up and retains discretion about whether to take any action, the Foundation pursues every consumer complaint to a conclusion, including litigation support if necessary. Unpublished statistics were obtained directly from the Foundation for Consumers.

57 Since 1996, the government has provided about half of the Foundation's funding. Subscriptions to Smart Buy comprise about $20 \%$ of the foundation's funding, and other donations make up the rest.

58 Constitution of Thailand 1997, s. 57; Constitution of Thailand 2007, s. 61. 
The Foundation's current campaigns emphasise a mix of familiar primary health care issues, including safe food and environmental safety (asbestos contamination is currently a focus of concern). ${ }^{59}$ Energy pricing and fraud committed by a chain of popular sports clubs are classic consumer issues that are also among the Foundation's current campaigns. More recently, the Foundation has taken up the issue of public transportation safety. As I explore in the following sections of this article, these issues represent a progression in goals of the consumer movement, from primary health care, to consumer action, to more sustained campaigns for policy change. The Foundation's description of its campaign for transportation safety includes a critique of the weak oversight and poor job of standard setting by the Ministry of Transportation, targeting change in Ministry priorities through direct political action. New strategies and new ways of encouraging action by the public have departed from the Thai-style NGO model of collaborating with and cajoling ministry insiders to expand, improve, or redirect their efforts. In addition to encouraging direct action by individuals, her legislative campaigns have a distinctly democratic and political form, mobilising public political pressure for action within a legislative and constitutional framework. Significantly, several of the campaigns have also employed a new social movement strategy which the Foundation has increasingly favoured, litigation.

Notwithstanding apparent success in establishing the complaint center and Smart Buy, in an interview by ThaiNGO.org in 2008, Saree said her threepronged project has not reached its goal. Fewer people have supported her projects than she anticipated, suggesting, she says, that Thai may still be enthralled by consumption and are still unwilling to invest resources in projects like hers that improve conditions for the general public as they do in more developed countries. ${ }^{60}$ But another dynamic may be at work. Despite Saree's concern about increasing the breadth of her audience, emphasis which Saree has given to self-help and consumer rights may have had unintended consequences. Consumers who "get" it, may not be ones she initially had in mind. Chairat Sang-arun, one of Saree's most trusted lawyer-experts, believes that the consumers who have responded to Saree's mobilisation efforts are mostly middle class because, as he says, "they are the ones who buy things." ${ }^{61}$ Chairat's remark suggests that the Foundation's focus on consumer self-help may have unintentionally changed Saree's constituency from poorer Thai, whose condition

59 The Foundation's current campaigns are described on its website. See "Campaigns" [in Thai] found at <www.consumerthai.org > (last visited 6 August 2013).

60 Interview with ThaiNGO.org, supra note 53.

61 Interviewed 22 June 2007 and 13 July 2011. 
motivated students in 1973 and who were the focus of international primary health care and consumer protection movements, to relatively wealthy and better educated members of the middle class in a prospering society. While many of the issues that the Foundation now addresses are of universal importance - from energy pricing to auto safety and the availability of appropriate medicines - consumer issues specific to Thailand's many poor rural communities and low wage laborers now seem overshadowed by her evolving national strategies. Nevertheless, according to a long-time consumer advocate and former OCPB official, Saree's independence from government and dedication to consumers continues to make the Foundation for Consumers a unique resource. Few other consumer advocacy NGOs have survived as long, the former official notes, and the Foundation for Consumers may be the only legitimate consumer advocacy organisation left in Thailand. ${ }^{62}$

\section{EMPOWERMENT THROUGH RIGHTS ${ }^{63}$}

By 1996, when Saree collaborated in creating the Foundation for Consumers, she viewed rights as a powerful resource which not only could change consumer behavior but also could change the system and alter the distribution of power. Saree's awareness of these possibilities for rights reflects a changing context for Thai NGO advocacy and the continuing evolution of the discourse of rights and constitutionalism begun in 1973. Although the Consumer Protection Act of 1979 provided for registration of NGOs which intended to litigate on behalf of consumers, the Ministry of Public Health failed to adopt regulations required for NGO registration under the Act until 1997. ${ }^{64}$ As described previously, a mid1970s study of Thai consumer behavior found that the vast majority of Thai consumers knew little about their legal rights, avoided making complaints about shoddy projects or fraudulent services, and resisted using courts. Recent research at least suggests that Thai perceptions of legal rights and formal remedies, administrative or judicial, have been slow to change. Significantly, the first NGO to apply to the Consumer Protection Board for permission to litigate on behalf of consumers did so in 2002, long after the 1997 constitutional reform and the establishment of the administrative court system. ${ }^{65}$

62 Interview with Professor Taewee Photipala, supra note 44.

63 Part VI draws heavily on prior work. See Munger, supra note 8.

64 Supra note 43.

65 Consumer Protection Association of Thailand, "History" found at $<$ http://www.comsumerprotection.or.th/index.php?mo=10\&art=579212> (last visited 6 August 2013). 
While Thai-style NGOs of the 1980s often pressured ministries to change their policies and encouraged greater popular engagement with government, litigation was rarely employed by activists as a means to achieve social change. Activists, especially lawyer-activists, were well aware of the importance of legal rights, and defended clients' interests in the civil and criminal courts. ${ }^{66}$ Thailand lacked what Charles Epp has called the "support structure for legal mobilization" that sustained public interest litigation in the United States or social action litigation in India. ${ }^{67}$ Epp suggested that "rights-advocacy organizations, rightsadvocacy lawyers, and sources of financing, particularly government financing" are essential elements of a support structure. His consideration of only common law based legal systems may have led him to overlook important characteristics of legal systems like Thailand's which have made litigation for social change less likely, such as fewer points of access because of the absence of meaningful constitutional rights, the absence of administrative courts, an "executive" or statist judiciary, ${ }^{68}$ and the limited training and capacity of attorneys to undertake social cause litigation. More fundamentally, there are many ways to characterise the claims of citizens against public and private power holders - as moral claims, as political demands, as legal or constitutional rights, or as human rights - each one with different implications for action to bring about change. Thailand's activists have skillfully employed multiple discourses and strategies to advocate for social justice. ${ }^{69}$ The changing role of rights and litigation has been driven by the mutual influence of institutional changes that have increased the accessibility of the legal system and the consciousness and capacity of lawyers who represent social causes. These changes, in turn, reflect a longer process of development extending back at least to 1973.

\footnotetext{
66 Interview with a former Union for Civil Liberties staff member, Sutin Borrommajet on 2 July 2008.

67 Charles Epp, The Rights Revolution: Lawyers, Activists, and Supreme Courts in Comparative Perspective (Chicago, IL: University of Chicago Press, 1998) at 2-3.

68 Kanishka Jayasuriya, "Corporatism and judicial independence within statist legal institutions in East Asia" in Kanishka Jayasuriya, ed., Law, Capitalism and Power in Asia: the rule of law and legal institutions (London: Routledge, 1999).

69 Bruce Missingham, The Assembly of the Poor in Thailand: From Local Struggles to National Protest Movement (Chiangmai, Thailand: Silkworm Press, 2003); Rapin Quinn, "Competition over resources and the local environment: The role of Thai NGOs" in Philip Hirsch, ed., Seeing Forest for Trees: Environment and Environmentalism in Thailand (Chiangmai, Thailand: Silkworm Press, 1996).
} 


\section{A. Lawyers for Social Causes}

The October Revolution created a generation of activists together with lawyeractivists who work with them. Law students joined visits to the countryside and slums as observers and teachers or to assist in other ways. They helped conduct research on social problems, and some joined the demonstrations or protests by workers and others both before and after the fall of the dictatorship. A few law graduates entered the Graduate Volunteer Service to serve as staff members of new NGOs. After 1973, law graduates could join projects to advise farmers about land rights or join a research team to study the problems of youth in poor communities or support social reform in many other ways. A few graduates found jobs in the small law firms which pursued a risky course defending labor leaders, political dissenters, criminals, and communists. In 1976, the young activists were forced into hiding or to flee to the jungle to escape arrest and prosecution.

In 1973, faculty members at Thammasat and Chulalongkorn established two NGOs that have had profound influence on legal activism in Thailand. The first was the Legal Services Center Institute, and although it did not survive the 1976 crackdown, many students affiliated with the Center became founders of NGOs of their own in the $1980 \mathrm{~s}^{70}$ The second was the Union for Civil Liberties (UCL), which has employed generations of activist lawyers. Between 1973 and 1976 the UCL received funding from European foundations to support its work on behalf of social movements for workers' rights and rural land security. ${ }^{71}$ Revived in the early 1980s, foreign support for UCL was limited because the military considered it staff sympathetic to communism. The UCL occasionally litigated to vindicate land tenure or defend individuals charged with crimes, but primarily it supported workers and other social movements by organising, conducting media campaigns, research, and education. ${ }^{72}$

Like the UCL, other NGOs founded in the 1980s by October Generation activists and which employed third generation lawyer-activists had resorted to litigation as a means to defend rights when necessary but not as a means of social change. Although lawyers were frequently in court to defend clients from criminal charges or to insure proper resolution of a particular conflict, neither lawyers nor judges were not trained to view litigation as a means of testing the

70 Ruangrawee Pichaikul \& James R. Klein, Legal Literacy for Supporting Governance: Legal Empowerment - Advancing Good Governance and Poverty Reduction (Bangkok: The Asia Foundation, 2005).

71 Interview with Sutin Borrommajet, 2 July 2008.

72 Ibid. 
broader policy implications of the law. ${ }^{73}$ Until enactment of an organic law establishing a system of Administrative Courts in 2000, Thailand had no easily accessible means of exercising oversight of the government's violations of law. ${ }^{74}$

Neither the elite ranks among practitioners nor the Thai Bar Association have historically undertaken or supported public interest law activities, much less lawyers' involvement in social change. ${ }^{75}$ From its inception, the Thai Bar Association has been dominated by judges and prosecutors - conservative, elite government employees, selected through highly competitive examinations that place them on a wholly different track from practitioners early on in their careers. The upper ranks of the private bar assert little political influence as a professional group and have seen little advantage in embracing the public interest as a cause. ${ }^{76}$

In 1985, the Thai Parliament chartered the Lawyers Council of Thailand, with a president and governing board elected by members of the practicing bar, to oversee licensing of attorneys and to organise activities to advance their interests. Parliament allocates a small fund for legal services for the poor administered by the Lawyers Council. Through the initiative of October Generation lawyers in the post-1997 constitutional period, the Lawyers Council of Thailand has emerged as an important focal point for activism.

Human rights and rule of law were not ideas widely understood in Thailand in 1973, and the terms have entered the vocabulary of Thai activists, in part, through mentoring by lawyers and intellectuals trained abroad, including prominent founders of the Legal Services Center Institute and the Union for Civil

73 Although the Thai judiciary historically has been relatively free from corruption and independent of direct political interference (in contrast to some other Asian judiciaries), it has traditionally been bureaucratic, concerned about career advancement, conservative, and unlikely to thwart government's purposes.

74 An occasional petition to the Council of State might result in a reversal of a bureaucratic decision. Although designed to provide a check on ministerial powers, the Council lacked independence from the executive and capacity to provide a comprehensive resource for control of government, nor did it create a culture of accountability or strengthen the rule of law. See Peter Leyland, "The emergence of administrative justice in Thailand under the 1997 Constitution" in T. Ginsburg \& A.H.Y. Chen, eds., Administrative Law and Governance in Asia: Comparative perspectives (London: Routledge, Taylor \& Francis, 2009).

75 Interviews with Somchai Homla-or, former Chair of the Human Rights Committee, Lawyers Council of Thailand on 21 December 2006 and 18 June 2007. Interview with Dej-Udom Krairit, former President of the Lawyers Council of Thailand on 11 December 2009.

76 Some leading Thai practitioners concede they are intimidated by the powerful bureaucratic state and are therefore reluctant to jeopardise good relationships needed to promote the interests of their business clients. Interview with the principal partner of a large (non-global) Thai law firm, 10 December 2009. 
Liberties. ${ }^{77}$ Somchai Homla-or is an October Generation lawyer, who worked for UCL and has subsequently played a unique role consolidating and orienting activist law practice toward human rights and litigation for social change. Following graduation from Thammasat Law School in 1972, Somchai worked with farmers protecting land rights. Forced to flee in 1976, he returned to become the manager of the UCL only to be forced to flee again for reporting the Thai military's treatment of Cambodian refugees to Amnesty International. While out of the country he interned at the Asian Human Rights Commission, toured Southeast Asian countries, and accepted an American Friends Service Committee fellowship in Washington, DC. He returned to Thailand in the late 1980s to become a leading voice for human rights and the rule of law.

Thailand's 1997 constitutional reform opened new avenues for lawyer activism. The prominence given to rights and the new court administrative and constitutional courts did not make rights more effective overnight, but they were promises waiting for development, in part because the public was aware of them. Soon after adoption of the new constitution, Somchai established a Human Rights Committee for the Lawyers Council, which he built into an influential network that included most of the lawyer-activists in Thailand - a mix of generations and a mix of small private practitioners and NGO staff lawyers. The lawyers were organised into expert committees to select cases and litigate them collaboratively using the new courts and the new constitutional principles. Somchai urged the lawyers to spend time educating social movement leaders about constitutional rights and to use litigation as a means to do the same for judges.

\section{B. Constitutional Reform}

Thailand's military-backed governments in the 1980s presided over rapid economic expansion. Notwithstanding Thailand's economic success, the military was unwilling to remain on the sidelines. In 1991, a military coup seized power from the civilian government. Protests in Bangkok arrayed an outraged middle class against military troops with resulting loss of many lives during "Black May," 1992. The shock of the mass violence and global attention brought Thailand's King into the conflict, and the military was forced to step back, creating a space for renewed demands for greater civic space and a more liberal

77 Interview with Saneh Chamarik, former Chair of the Thailand Human Rights Commission on 22 December 2006. Interview with Gothom Arya, founder and former Chair of the Union for Civil Liberties on 22 December 2006. 
constitution. ${ }^{78} \mathrm{NGO}$ leaders and liberal intellectuals from the October Generation played important roles in Thailand's first, sustained public debate about political alternatives and the importance of a more liberal constitution. With the support of foreign donors, NGOs conducted an outreach campaign to the public, holding forums across Thailand to inform ordinary people and to encourage their support for a constitutional referendum. The public responded with overwhelming support.

The Constitution of 1997 is known as the People's Constitution because of the influence of the NGOs' and intellectuals on the issues raised by the public debate and their subsequent influence on specific provisions, especially the Constitution's protections for rights. Rights were central to the public discourse of constitutional reform. Some NGO staff members express the belief that popular consciousness of constitutional rights became widespread in Thailand as a result and that this has changed the terrain on which they work. Among other guarantees, the 1997 Constitution and its successor in 2007 named consumer rights and authorised an organic act establishing an independent consumer protection agency.

Less prominent in the public debate but critical to the outcome, leading intellectuals promoted structural reform, including a popularly elected Prime Minister, a Constitutional Court with powers of judicial review, independent oversight boards for critical government functions, and administrative courts. A reluctant military and entrenched elites resisted until the Asian Fiscal Crisis of 1997 aligned the business community with the reformers. Although the liberal 1997 Constitution was viewed by some scholars as an achievement comparable to the South African Constitution which ended apartheid, Thailand's subsequent political upheavals - a coup in 2006, followed by a new Constitution in 2007, and continuing challenges to stability - suggest that fundamental change in the structure of power in Thailand has been incomplete. Yet, the structural reforms have remained in place, and they have begun to alter the landscape for political participation and advocacy for social movements.

78 Prime ministers Anand and Chuan following the coup were sympathetic to NGO collaboration in policy development and implementation and provided funding for them. Foreign funders encouraged the discussion of Thailand's political future by supporting think tanks, NGO outreach to the public, and preparations for drafting a new Constitution. Baker \& Phongpaichit, supra note 2. 


\section{Administrative Courts and FFC Litigation for Change}

Even before the establishment of administrative courts, staff members at the Foundation for Consumer's Complaint Center might advise an individual with a complaint to consult a lawyer about legal remedies under the civil and commercial code, and the Center maintained a list of volunteer attorneys who agreed to provide assistance without charging a fee. ${ }^{79}$ Legal remedies available prior to 1997 were limited, but the administrative courts system created new opportunities for remedial litigation. Modeled largely on the French administrative courts but given greater remedial power, the Thai Administrative Courts were intended to provide accessible forum for challenging the actions of the Thai government. ${ }^{80}$ Citizens may file their own petitions and court personnel are instructed to help them with their petitions, making lawyers unnecessary as a formal matter. ${ }^{81}$ The Consumer Case Procedure Act of 2008 (CCPA) made consumer litigation easier. The Act created the position of "Case Officer" to assist in the handling of cases to make certain that parties were adequately represented..$^{82}$ The Act requires good faith performance of legal obligations by sellers and manufacturers. ${ }^{83}$ The Act also authorises punitive damages in certain cases, double the actual damages for claims over 50,000 baht and up to five times actual damages for claims under that amount. ${ }^{84}$ The year following passage of the CCPA, the Foundation's volunteer attorney pool reached its maximum of about 30 attorneys who filed nearly 80 cases. The fact that the CCPA was proposed by members of the judiciary under a new clause in the 2007

79 Chairat believes that some of the lawyers may hope to make contacts leading to future feepaying business, but most of them genuinely believe in consumer rights. Interview on 13 July 2011.

80 Peter Leyland, "Genealogy of the administrative courts and the consolidation of administrative justice in Thailand" in Andrew Harding \& Penelope Nicholson, eds., New Courts in Asia (London: Routledge, Taylor \& Francis, 2010).

81 Act Establishing the Administrative Courts and Administrative Court Procedure of 1999, s. 45. Administrative Court judges need not be career bureaucratic judges from the established judiciary but may have more varied experience and a broader background. Section 13 . The first chief judge of the administrative court system was a leading member of the Council of State who had strongly advocated a more formal, accessible, and system of courts under law for oversight of bureaucratic decision making. Notwithstanding these provisions making access easier, many consumers report that judges have rejected petitions, urging the plaintiff to obtain the assistance of a lawyer before returning to court.

82 CCPA, s. 4.

83 CCPA, s. 12.

84 CCPA, s. 42. 
Constitution may also be evidence that judges have embraced the opportunity to assume a more active and independent role. ${ }^{85}$

Since 2009, however, the number of litigated Complaint Center cases has declined steadily, and the number of volunteers has declined from a high of about forty to just a handful over the past few years. Administrative Court judges have become stricter about accepting cases, telling plaintiffs to find a lawyer and dismissing more cases. Leading Foundation litigator, Chairat Sang-arun, notes that the administrative courts have proven less accessible to individuals than he thinks they were intended to be. Another experienced lawyer in Saree's network, Nitithorn Lamleur, thinks in general the number of activist lawyers is declining. But by increasing the damages in consumer cases, the CCPA may have made it easier for consumers to find lawyers on their own. A Complaint Center legal staff member says a third factor is also at work, which is the Foundation's decision to place greater emphasis on cases which have a significant impact. Overall, the number of cases brought by consumers seems relatively small given the ease of filing and incentives after the 2008 reform. A study by the Lawyers Council showed that only $4 \%$ of more than 80,000 "consumer cases" reported by the civil courts over an 8-month period in 2013 were brought by consumers; the remaining $96 \%$ were brought by companies suing consumers for payment or suing other companies under contract, product quality, trademark laws or other causes of action. ${ }^{86}$ Some consumers who have attempted to bring cases without assistance of an attorney have reported that judges have repeatedly rejected their petitions and advised them to hire an attorney before returning. ${ }^{87}$ The Foundation itself has facilitated (or litigated itself) just over four hundred cases (Foundation for Consumers 2011).

Saree saw the promise of using the law to leverage major policy changes long before the new Constitution created administrative courts, but the pre-1997 process for challenging the legality of bureaucratic decision making was far

85 Constitution of Thailand 2007, s. 139(3).

86 Found at www.bangkokbiznews.com reported 4 February 2009 (last visited 5 August 2013). Professor Taewee Photipala, former OCPB public relations director and long-time consumer advocate says consumer behavior has changed little over the past four decades and few are willing to litigate. Most consumer cases are about bigger ticket items and brought by relatively well-to-do consumers. See supra note 44.

87 Thai litigants who need a lawyer encounter another barrier - the attorney's fee. Thailand's Code of Civil Procedure does not permit contingent fees. Potential plaintiffs but must agree to a fixed fee to be paid whether the case is successful or not. Reportedly, this limitation is widely ignored but fees in violation of the code risk invalidation by the court, making attorneys more reluctant to take cases involving the broad standards by which consumer protections are judged. 
more difficult and uncertain. In 1994, she brought her first case, with Chairot's assistance in its later stages, challenging the merger of two cable TV stations under Thailand's competition law. Her challenge to the merged TV station, UBC, was exceptional because it was lodged with the functional predecessor to the administrative courts, the Council of State. Petitioning the Council of State formalised the ancient process for petitioning the King for relief. ${ }^{88}$ The Council of State took no action on her petition, eventually referring the case to the new administrative courts. Saree maintains that, notwithstanding the infrequency of favourable Council of State rulings, the value of the petition lay in the publicity it generated as a vehicle for public education. The Administrative Court eventually ruled in the government's favour, but Saree said the decision also benefited the Foundation for Consumers by upholding the Foundation's right to litigate a case for the public interest even though it was not a "consumer case" authorised by the Consumer Protection Act of 1979.

Since 2000, the Foundation has begun to take important cases to the administrative courts, and the courts have responded with a handful path breaking legal decisions striking down government policies. The ability to litigate complex cases effectively has depended on lawyers from Somchai's network who understand the political purpose of her litigation, who have experience in litigation, and who are willing to invest their time without compensation. Chairat's firm is representative of a small number of firms established before 1973 by activists who have supported and mentored a younger generation of activist-practitioners. Most of the firms have survived by accepting business cases as well as political or social movement cases, and they have focused largely on legal work rather than direct involvement in political or social movement activities. Yet many of these individuals embrace the idealism of 1973 and are well-known among NGO leaders. Their style of practice for NGOs is often distinctive, involving teaching social movement leaders about their rights, collaborative planning of litigation with other activist lawyers and movement leaders, and expecting little in the way of compensation from clients. ${ }^{89}$

Many of the Foundation's important cases in the administrative courts have been unsuccessful, but one attorney who has worked with Saree says that the

88 Petitions to the Council were sometimes made on behalf of social movements, but they were often a political move rather than a legal one. Farmers contesting seizure of their land in northern Thailand submitted petitions in the 1970 to contest land seizures they considered unjust. The Assembly of the Poor petitioned to prevent the Pak Moon Dam from submerging their villages in the Northeast. See Missingham, supra note 69.

89 Interviews with Somchai Homla-or 21 December 2006 and 18 June 2007; Nakorn Champhoochat 15 June 2007; Nitithorn Lamlhuea 22 June 2007 and 15 July 2011; Chalit Meesit 13 December 2012. 
point of the Foundation's litigation is often publicity for an issue regardless of the outcome. ${ }^{90}$ The Foundation, he says, is "demonstrating a new way of making demands on the government." Under Saree's guidance, selection of cases for litigation by the Foundation has been, in part, politically opportunistic and many cases have been chosen for public impact rather than part of plan to build doctrine more favourable to consumers. As Chairat observed, a number of Foundation cases brought during the regime of Prime Minister Thaksin Shinawatra were intended to publicise his attempts to profit from privatisation at the expense of the public. Further, the Foundation sought to stop programs and projects or expose major safety hazards without attempting to use the courts to establish new policies. In part, this reflects the civil law origins of the Thai legal system, in which courts do not make policy, but Thai high court judges well understand the broader impact of their decisions on lower courts and other cases. $^{91}$ In part, case selection reflects the decision process within the Foundation itself. Some issues that might be litigated are proposed by member NGOs which oppose a ministerial policy or program. The UBC case described earlier is such a case, brought to CCPN by a telecommunications NGO, and a current case against Abbott Pharmaceuticals, also under the Thai competition law, is another example. Although Saree describes the issues as a reflection of grassroots interests, the Foundation's leaders, including Saree and one or two of her closest associates, initiate these decisions. Occasionally, a member NGO will suggest an issue. ${ }^{92}$ But member NGOs, like the Foundation itself, are often guided by experts versed in policy and technical issues.

An example of Saree's case selection is the Foundation's case to stop privatisation of the Electrical Generating Authority of Thailand (EGAT) by Prime Minister Thaksin Shinawatra. In 2005, the Foundation was already preparing to focus on highly technical electrical pricing issues when it learned, unexpectedly, that the Prime Minister planned to sell EGAT to private investors within a few days. Saree and her close advisors concluded that the sale of the enormous public utility would have little benefit for the vast majority of Thai citizens who could not participate in the purchase of stock. Saree filed a petition in the administrative courts to block the sale without consulting experienced litigators, and only after her case was threatened with dismissal did she and her staff seek litigation assistance from the network of activist attorneys. Fortunately, she found an attorney who was able to mount a creditable attack

90 Interview with Nitithorn Lamlhuea (interviewed by Worrawan Jirathanapiwat), 18 May 2013. 91 Interview with Appellate Court Judge Prinya Deepadung, 1 July 2009.

92 Interview with Saree Aongsomwang, 11 July 2011. 
on the EGAT sale on a few days' notice. ${ }^{93}$ The Foundation prevailed, thwarting the controversial Thaksin privatisation plan and making history for the Thai administrative courts and the rule of law. ${ }^{94}$

Although Saree clearly likes a good fight - policy work, she says, is boring the Foundation has become more attentive to the uses of litigation to develop policy. Recent litigation by the Foundation has focused on issues of transportation safety and pricing. ${ }^{95}$ The Foundation's transportation litigation is part of a campaign employing other methods of mobilising public involvement through creative tactics that have characterised Saree's other campaigns. In addition to litigation, for example, the Foundation conducted auto inspections, reporting the results to the media in order to encourage adoption of a law which would require all owners to have their vehicles inspected. This change from the Foundation's earlier pattern of purely opportunistic case selection may, nevertheless, be the exception which proves the rule, because the Foundation's program has been influenced by the availability of substantial amounts of government funding to publicise transportation safety issues. ${ }^{96}$ The funding stream, opportunistic as it is, has given the Foundation's advocacy consistency and a longer horizon.

\section{RightS IMAgINED - TWO CONTEMPORARY EXAMPLES}

Advocates for both the consumer and environmental movements in Thailand use the term "empowerment" to describe movement strategies and their role, a commitment with its roots in the legacy of 1973. They share strong ideological

93 The Foundation has legal officers who may not be attorneys and who lack the experience of Chairat and Nitithorn.

94 The Foundation's victory in the EGAT case is not an isolated example, nor is the Foundation for Consumers the only NGO to have discovered the potential benefits of social reform litigation. In the next Part, I briefly compare the litigation experience of another social movement. Peter Leyland cites this case as a leading example of the independence and power of the new administrative courts (Leyland, P. 2009). FFC's attempt to block privatisation of another major utility, Thailand's state owned petroleum and gas company [PTT] in 2007 was dismissed on technical grounds. See Matichon, 13 December 2007 [in Thai] found at <http://news.sanook. com/politic/politic_224614.php> (last visited 26 June 2013).

95 Foundation For Consumers, เหยื่อ อุบัติเหตุรถตู้โดยสารสุดทน!!! [Accident Victims Are Fed Up!!!], 5 July 2012, found at <http://www.consumerthai.org/main/index.php?option=com_content\& view=article\&id=2369:2012-07-05-14-06-08\&catid=132:2010-11-05-07-01-51\&Itemid=188> (last visited 31 December 2013).

96 Ibid. 
commitment to constitutionalism, political reform, government accountability, and more effective mobilisation of the groups they represent to redress the influence of powerful private interests. ${ }^{97}$ These are ideological orientations of the October Generation and later generations of advocates for social change. Since 1973, opportunistic development of advocacy strategies on behalf of Thai social movements has reflected changing institutions and politics, and especially the recent constitutional changes and their effects on Thailand's court system. The influence of four decades of political change on movement leaders, their careers and the movements they lead, can be perceived more clearly by comparing the role of law in the consumer movement advocacy with the role of law in advocacy for another Thai social movement which recently won noteworthy litigation victories, the environmental movement. ${ }^{98}$ Although the consumer rights and environmental rights movements share roots in the uprising of 1973 and the democratic opening that followed, they have negotiated the institutional limitations and opportunities created by Thailand's political and legal systems in different ways.

In preceding sections of this article, I have described the relationships between advocates for the movement for consumer protection and the government that shaped both the cause itself and the means employed. Relatively recent constitutional changes, together with mobilisation of litigators by enterprising leaders of the activist bar, have made litigation by the consumer movement an attractive strategy for gaining publicity and demanding accountability. The influence of circumstances beyond "law on the books" is demonstrated by the nearly 25 year lag between the Consumer Protection Act of 1979s authorised NGO litigation for consumers and the first cases brought by an NGO using this authority. The Thai Environmental Protection Act, adopted in 1992, has also had an afterlife through litigation begun after the Constitution of 1997 reformed the court system. The strategies of both movements were influenced by the constitutional reforms of 1997 and a judiciary which is seemingly increasingly ready to demonstrate independence. Yet the movements have adopted quite different litigation strategies. Until recently, litigation by the Foundation for Consumers was opportunistic, staged interventions to stop widely publicised government projects or gain admission of wrongdoing from a private manufacturer. There has been little apparent concern about the impact of the outcome of litigation on the law itself or the future of the movement. As the attorney who litigated the EGAT case for the Foundation for Consumers said, Saree and the Foundation

97 Pichaikul \& Klein, supra note 70.

98 Frank W. Munger, "Global Funder; Grassroots Litigator - The Judicialization of the Environmental Movement in Thailand” (2009) 9 International Review of Constitutionalism 75. 
litigate primarily for publicity. The measure of the success of this strategy will not be changes in the law but the growing commitment of individual consumers to their own welfare through better market choices and effective action to protect their rights.

One of the leaders in environmental litigation is Surachai Trong-ngam, whose career, like Saree's began in the late 1980s. ${ }^{99}$ Discovering his interest in activism as a law student at Thammasat through activities in the countryside and by reading books on radical law practice and politics, Surachai became a respected radical himself who has had a strong influence on later generations of students. As a staff attorney for a Thai-style NGO, Friends of Women, he became known as a skillful litigator, and through friends at several anti-pollution NGOs his advice was sought by community groups resisting industrial development. In 1999, the network of environmental activists selected Surachai as director of a new NGO, EnLaw, which received funding for anti-pollution litigation from a New York-based foundation.

EnLaw attracts funding and supports environmental litigation with Surachai as its director, much like the Foundation for Consumers. But in other respects, EnLaw is very different from the Foundation. The leading environmental advocates who serve on EnLaw's board develop new projects and ideas for litigation, directing Surachai's work. EnLaw has no cause bureaucrats from government ministries on its board and few ties to them. The difference has had consequences, not only for the objectives of Surachai's litigation but also for funding, which must be sought from foreign foundations and other non-governmental sources, in contrast to $\mathrm{FFC}$ which receives about half of its funding from government projects.

Surachai's litigation practice is nearly unique among NGO attorneys. First, he has been supported by a strong coalition of experienced environmental advocates with NGOs of their own who obtained initial funding and selected him. Their focus has had a strong influence on EnLaw's and Surachai's dedication. However, one reason that Surachai was an attractive candidate for the position was his demonstrated litigation skills and his principled approach to working with the communities and other clients he represents. Surachai's law firm, which does EnLaw's legal work, has become the "go to" firm for the defendants in recent government lese majeste and computer crimes act prosecutions. Surachai considers himself a social movement attorney who specialises in legal expertise but who supports his client's movement goals, even when they reject his legal advice, or use his advice to achieve purposes other than an

99 Interviewed 16 June 2007, 27 February 2008, 28 June 2008, 30 June 2009. Like Chairat and Nitithorn, he is from a poor family in the south of Thailand. 
outcome at law. He has retained a strong relationship with leading academic experts in administrative law, relationships which have contributed to the sophistication and success of his litigation on behalf of his clients. He is mentor to a younger generation of litigators who serve NGOs and represent defendants in political cases.

A further distinctive feature of Surachai's practice is the nature of his clients. Unlike the Foundation for Consumers, EnLaw and Surachai work with wellmobilised and goal-oriented communities which have their own leaders. Surachai enters the picture at his clients' request rather than seeking to become the catalyst for mobilisation. The environmental movement is one of the most well-developed social movements in Thailand, not only because a few global organisations (such as the World Wildlife Federation) and European foundations (notably the Heinrich Boell Foundation) have made long-term commitments to facilitating community action for environmental defense but also because many of its clients are communities with skillful leaders. Because the goals of his clients are relatively clear and long term, and because his relationship with them is also relatively long term, Surachai can use litigation to "play for rules." 100 For example, Surachai has carefully identified areas of judicial authority over standards of care established by Thai ministries charged with oversight of actions which have an environmental impact. Surachai brought one of the first cases decided by the administrative courts, in 2000, in which the administrative court issued an unprecedented holding that a Thai ministry had failed to set sufficiently high standards for disposal of radioactive waste material. In 2009, he was part of a team of litigators which won an internationally acclaimed decision by the Supreme Administrative Court to shut down one of Thailand's largest industrial parks for failure to observe proper air quality standards. ${ }^{101}$ Although appeals have sometimes limited or reversed initial successes, his strategy for seeking major policy interpretations that will have broad impact on other communities is similar to successful public interest litigation in countries such as the United States or India.

There are three important differences between the post-1973 movement strategies adopted by Saree and Surachai and the NGOs they represent: the

$\mathbf{1 0 0}$ The term has been popularised by Galanter to describe one of the advantages of "repeat players" who have sufficient resources to make strategic use of litigation. Marc Galanter, "Why the 'Haves' Come Out Ahead: Speculations on the Limits of Social Change" (1974) 9 Law \& Soc' Rev. 95.

101 Administrative Court News, \#74/2009 คำสั่งศาลปกครองสูงสุดในคดีคำร้องที่ ๕๕๖/๒๕๕๕๒ (คดีมาบตาพุด) [Opinion of the Supreme Administrative Court in case 586/2552 (The case of Map Ta Phut)]. 
relationship between their founding networks and their strategies, the sources of legitimacy of they have cultivated, and the importance they have attributed to legal rights. The networks which shaped Saree's and Surachai's careers not only created opportunities which provided a starting point but also shaped their understanding of the social cause they represented and the possibilities for subsequent career steps and strategies. I have tried to show how closely connected the Thai primary health care and consumer movements were at the outset, and in turn the way that an international discourse of development provided powerful framework for the movement. For reasons unique to Thailand, both internal politics and institutional arrangements created points of connection between domestic politics and the international discourse. While Saree has many personal connections among the diaspora of grassroots human rights advocates, the core of her influential network has been her close connections with those who served in government ministries. Her strategies for improving implementation of national policies have often had the support of liberal members of Thai ministries.

Surachai proved receptive to the radicalism of the uprising and its intellectual foundation, which he absorbed in some depth. He became deeply embedded with October generation NGO leaders and at the same time retained connections to (and the admiration of) his law school mentors and peers. ${ }^{102}$ Surachai has cultivated no relationships within government, but rather has identified his efforts with empowerment of local constituencies and limiting arbitrary use of government power.

Second, following from the differences in their networks and causes, we can anticipate difference in the ways that Saree and Surachai seek legitimacy for their movements. Sociologist Arthur Stinchcombe has described the legitimacy of authority (and indeed all structure) as built upon "chains of contingent activities," through which "third parties interven[e] in case of need" (1968:150-1). In other words, a claim to power is legitimate when its authority is supported by other power-holders. Establishing relationships with power holders that support the advocate's claims for justice may thus be the essence of all social cause advocacy, but especially in societies where institutions, like courts, that might demand accountability from those with power are relatively weak. Litigation has only recently become an important strategy for change in Thailand, and both before and after 1997, mobilising support for social causes

102 Twenty years after first meeting Surachai as a student, who was then a senior at Thammasat University, the associate dean at the law school has placed Surachai's photograph on his office wall - beard, torn jeans, a cloth shoulder bag, looking like a Thai Jack Kerouac in a rice field. 
proceeded mainly by other means. Again, Saree has had access to government officials and influential elites in the medical profession. Further, her creative publicity campaigns are intended to have broad public appeal in order to encourage citizens to demand that ministries and private companies honor their responsibilities toward members of the public. Surachai has sought leverage over decisions made by the government, but he has never sought legitimacy through networks linking his project to government. Instead, his clients have achieved legitimacy through collective community action, publicity, and through litigation. ${ }^{103}$ Somchai Homla-or, who is perhaps Thailand's best known human rights lawyer, praised EnLaw as an achievement by a new generation of Thai human rights lawyers who use law to advance local participation and popular empowerment. ${ }^{104}$

Third, as the movements have matured, they have increasingly found an important role for rights. The increasing importance of rights in social movements in Thailand reflects a changing institutional structure and its reciprocal relationship to political change. Enactment of the Constitution of 1997 was a particularly important milestone reflecting the growing demand for participation and accountability. Enactment of the Constitution and its provisions for a more independent court system did not occur in isolation from the slow process of change that created an opening for constitutional reform and will determine its influence. In many subtle ways, this change was anticipated by an incremental increase in the legitimacy of human rights globally and among liberal intellectuals and activists in Thailand. Once the term "rights" entered the picture, however, Saree and Surachai's uses of the concept revealed important differences between their commitments to social change. Saree's concept of rights decentralises the focus of her reform to the individual and suggests the importance of enhancing possibilities for individual action. Her concept of rights is consistent with a modern concept of the citizen whose very identity is shaped by the rights and responsibilities of citizenship. Surachai employs the concept of rights to express the responsibilities of the State and limitations placed on its power. For him, and the social movement advocates with whom he works, rights empower communities by giving them a legal status which they previously lacked.

103 EnLaw, Environmental Justice: Essays and Interviews About Environmental Justice Law Suits (Bangkok: EnLaw, 2008).

104 Somchai Homla-or, "Introduction" in Darunee Panichkul, ed., Environmental Justice: Essays and Interviews About Environmental Justice Law Suits (Bangkok: EnLaw, 2008). 


\section{Conclusion}

In this article, I have traced the evolution of NGO-based advocacy in Thailand for consumer protection with the purpose of showing its debt to "revolutionary" thought and practice that characterised activism in the 1973 over throw of the Thai dictatorship. Through the career of one of the most important advocates for the cause, it has been possible to examine a larger landscape. Over time, the goals and strategies of the leading advocate for consumers and of her network of NGOs and collaborators have evolved to respond to new interpretations of the cause but also to maintain the viability and effectiveness of the advocates - their power and legitimacy within Thailand's social and political institutions. Over four decades of adaptation and change many of the methods of social activism by NGOs remain the same, such as maintaining close relationships with "cause bureaucrats" and others receptive to NGO's offer of expertise and capacity. Latent interest in human rights and constitutional reform surviving from 1973 positioned NGOs for an important role during the political opening for constitutional reform in the 1990s. In turn, constitutional liberalisation has made it possible for NGOs to push the meaning of rights in social cause advocacy. Since 1997, an important turn in Thai social advocacy has been apparent toward making rights active in social change. I have suggested that this turn has had the unintended consequence for the consumers' movement of creating a selective appeal for citizens prepared to take rights seriously together with the trust and investment in public institutions such as courts that they require.

Further, I have compared advocacy for consumers with advocacy for environmental causes. Both sustained efforts at social change have kept ideas about empowerment from the October Generation in play and have created opportunities for empowerment and participation at the margins of other forces, both international and domestic. I have attempted to illustrate the range of strategic choices available to advocates for each social cause and the reasons for the differences in their strategies. Advocacy for consumers and for communities challenging projects damaging to the environment have been influenced by differences in possibilities for networking, alliances that bring material and symbolic (legitimation) resources to their causes, and the role that rights can play. Like the different ways of mobilising the forces of change that set the events of 1973-1976 in motion, contemporary social cause advocacy reflects the evolution of networks of power within the Thai political system.

Today the "rule of law" is an important element of contemporary Western theories of development, associated with the World Bank and the Washington Consensus, which maintain particular legal institutions are required for 
successful economic and political modernisation. ${ }^{105}$ The network view of law's power illustrated in this case study suggests, on the contrary, that a rule of law has organic origins, requiring state institutional capacity, but more fundamentally in the case of social cause advocacy, capacity and desire to mobilise rights on the part of those who seek power to challenge public or private authority. In turn, the capacity to mobilise law is embedded in networks of relationships that influence expectations and understandings of what rights can do. Rights are a resource which may be embedded in networks in different ways and with different purposes and limitations.

The evolution of Thailand's political institutions through constitutional reform and the increasing politicisation of the rural population had important effects on advocacy by Thai-style NGOs. ${ }^{106}$ The Foundation for Consumer's increasing reliance on publicity through national media, legislation through Parliamentary lobbying or popular referenda, and litigation suggests adaptation to the changes. Adaptations to political change must not be taken as evidence of the inevitable transformation of Thai-style NGOs into public interest groups similar to those that lobby and litigate in more developed democracies. The Foundation for Consumers may be one of the NGOs furthest down this road, in part because of the disaggregated nature of consumer interests in a relatively developed economy, an aspect of consumer advocacy of which Saree Aongsomwang has been acutely aware. Yet the Foundation and other Thaistyle NGOs continue to find the legacy of collaboration with a network of sympathetic insiders an important means of advancing empowerment for social causes, including the cause of rights, in a democracy still coming to terms with the influence of its historically dominant elite.

Acknowledgements: I am especially grateful to those I interviewed for this project who were patient, helpful, and generous with their time. I received helpful instruction about particulars of Thai statutory law from Professor Amnat Wongbandit. The dedicated support I have received from my Bangkokbased research assistants, Peerawich Thoviriyavej and Vorapitchaya Rabiablok, included many suggestions about relevant sources and the substance of the essay. I would also like to thank Worrawan Jirathanapiwat who assisted me with some of the interviews. This research has been made possible by generous support from the Law School Admissions Council and New York Law School.

105 Frank Upham, “The Rule of Law Orthodoxy” in Thomas Carothers, ed., Promoting the Rule of Law Abroad: In Search of Knowledge (Washington, DC: Carnegie Endowment for International Peace, 2006).

106 See Walker, supra note 26; McCargo, supra note 4. 